\title{
An Ultra-Miniaturized MCPM Antenna for Ultra-Wideband Applications
}

\author{
Ahmed Jamal Abdullah Al-Gburi*, Imran Mohd Ibrahim, Zahriladha Zakaria \\ Faculty of Electronics and Computer Engineering, Universiti Teknikal Malaysia Melaka (UTeM), \\ Hang Tuah Jaya, 76100 Durian Tunggal, Melaka, Malaysia
}

(Received 16 August 2021; revised manuscript received 20 October 2021; published online 25 October 2021)

\begin{abstract}
In this paper, an ultra-miniaturized modified circular printed monopole (MCPM) antenna is proposed for ultra-wideband (UWB) applications. The proposed antenna consists of four circular discs connected to the structure of the MCPM antenna, which leads to enhancing the antenna impedance bandwidth. The stated MCPM antenna is fed by a coplanar waveguide (CPW) to achieve a $50 \Omega$ impedance matching. A Rogers RT5880 substrate $\left(\tan \delta=0.0004\right.$ and $\left.\varepsilon_{r}=2.2\right)$ is employed for design simulation. The proposed UWB MCPM antenna is designed and simulated for frequencies from 3 up to $11 \mathrm{GHz}$ utilizing computer simulation technology (CST) software. The MCPM antenna is successfully designed and simulated, and its parametric study is performed in a comprehensive way to validate the design novelty. Furthermore, the proposed antenna shows a stable radiation pattern with good gain in the operating band. The stated antenna is also compared with the related literature reviews to differentiate its performance. The total dimension of the finalized antenna is $0.15 \lambda_{0} \times 0.15 \lambda_{0} \times 0.0016 \lambda_{0}$ that corresponds to the lowest operating frequency of $3 \mathrm{GHz}$. The finalized MCPM antenna achieves peak gain of $3.2 \mathrm{~dB}$ and directivity of $3.9 \mathrm{dBi}$ with high efficiency of $85 \%$ at $11 \mathrm{GHz}$. Besides, the antenna offers a wide enough bandwidth to be used for UWB and radio communication applications.
\end{abstract}

Keywords: MCPM antenna, Ultra-miniaturized, Gain, Ultra-wideband (UWB), Coplanar waveguide (CPW).

\section{INTRODUCTION}

The employment of ultra-wideband (UWB) has already been adopted worldwide, whether by global or government individuals who set various guidelines and instructions for UWB usage. In 2002, the Federal Communication Committee (FCC) certified the use of bandwidth frequencies from 3.1 up to $10.6 \mathrm{GHz}$ without the need for any license for UWB applications and to avoid interference with the existing bands [1]. UWB offers a high data rate of $500 \mathrm{Mbps}$ at $3.5 \mathrm{~m}$ using the lowest power in a short range of frequencies [2]. Moreover, UWB can propagate without the need for any radiofrequency (RF) devices.

Due to the advantages of UWB mentioned above, Apple company has launched the U1 chip using UWB technologies to localize and find the lost items.

The study and design of UWB antennas are more challenging than traditional narrowband antennas as the performance of the following antennas is estimated at the center of the frequency. Printed antennas are primarily used in antenna engineering due to the advantages of lightweight, less volume, low cost, and easy integration with a printed circuit board (PCB). Traditional printed antennas have inherent low gain, narrow bandwidth, and complexity in the design.

Many techniques have been reported to overcome the bandwidth and size limitation, which include the use of notch filter slots as a split ring resonator (SRR) [3-5], electromagnetic bandgap (EBG) [6], coplanar waveguide (CPW) fed [7] and partial ground plane feeding technique [8]. Moreover, different patch shapes have also been presented in this literature to obtain UWB response, such as hexagonal shaped [9], bioinspired leaf shaped [10], strawberry artistic shaped [11], modified trident shaped [12], simple flower shaped [13], modified pentagon shaped [14], Mercedes radiating shaped [15] etc.

However, most of the mentioned antennas are limited to the unlicensed use of UWB frequencies from 3.1 to $10.6 \mathrm{GHz}$ only. The dimensions of the antennas are also relatively larger. Table 1 presents a comparison of printed antennas in published works.

Table 1-Performance comparison of the proposed UWB antennas

\begin{tabular}{|c|c|c|c|}
\hline Ref. & $\begin{array}{c}\text { Antenna } \\
\text { size }(\mathbf{m m})\end{array}$ & $\begin{array}{c}\text { Bandwidth } \\
(\mathbf{G H z})\end{array}$ & Patch shapes \\
\hline$[3]$ & $24 \times 14 \times 0.8$ & $3.85-12.38$ & Circular \\
\hline$[4]$ & $32 \times 32 \times 1.6$ & $2.572-10.746$ & Rectangular \\
\hline$[9]$ & $56 \times 38 \times 1.6$ & $2.6-11.4$ & Hexagonal \\
\hline$[11]$ & $26 \times 26 \times 1.6$ & $3.05-11.9$ & Strawberry \\
\hline$[12]$ & $66 \times 62 \times 1.6$ & $2.4-12$ & Trident \\
\hline$[13]$ & $50 \times 42 \times 1.6$ & $3-11$ & Simple flower \\
\hline$[14]$ & $12 \times 22 \times 1.6$ & $3.8-11.7$ & Pentagon \\
\hline$[15]$ & $50 \times 50 \times 1.6$ & $2.1-12.6$ & Mercedes \\
\hline This work & $15 \times 15 \times 1.547$ & $3-11$ & Modified circular \\
\hline
\end{tabular}

In this paper, the design of a modified circular printed monopole (MCPM) antenna with a coplanar waveguide (CPW) as a feeding element is depicted. The proposed antenna exhibits an ultra-wideband response from 3 to $11 \mathrm{GHz}$. The antenna has a very compact size of $15 \times 15 \times 1.548 \mathrm{~mm}$, which is the smallest compared to those proposed in the literature [3, 4, 9, 11-15]. A summary of the contribution to the body of knowledge in this paper is given below:

1. A new shape of UWB antennas was proposed, which is an MCPM antenna, and it obtained a bandwidth of $8 \mathrm{GHz}$ from 3 to $11 \mathrm{GHz}$.

\footnotetext{
*imranibrahim@utem.edu.my
} 
2. The MCPM antenna has ultra-miniaturized physical dimensions of $15 \times 15 \times 1.548 \mathrm{~mm}$.

3. A comprehensive parametric study was proposed to validate the design procedures.

\section{MCPM ANTENNA DESIGN AND PARAMETRIC STUDY}

The geometry of the proposed UWB MCPM antenna is shown in Fig. 1. The finalized antenna, which used the Rogers substrate for the simulation process, has a thickness $\left(H_{t}\right)$ of 0.062 inches, that equals $1.575 \mathrm{~mm}$.
This helps to shift the lowest frequency, as also presented in Fig. 3. Resonant frequencies from 3.8 to $6 \mathrm{GHz}$ are out of range which is over $-10 \mathrm{~dB}$. After that, to increase the resonant frequencies, a small circle was added to enhance the radiating element, as shown in Fig. 2 (case 3). Then, to facilitate the impedance matching work over the entire UWB range, one more circle was proposed, as shown in Fig. 2 (case 4). The antenna in case 4 provides an impedance bandwidth of $3.224 \mathrm{GHz}$ to $11 \mathrm{GHz}$, as duplicated in Fig. 3, which is higher than the proposed antennas in cases 1,2 , and 3 .

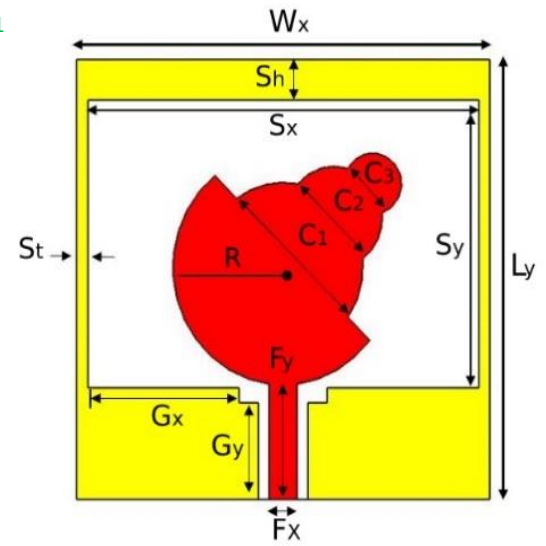

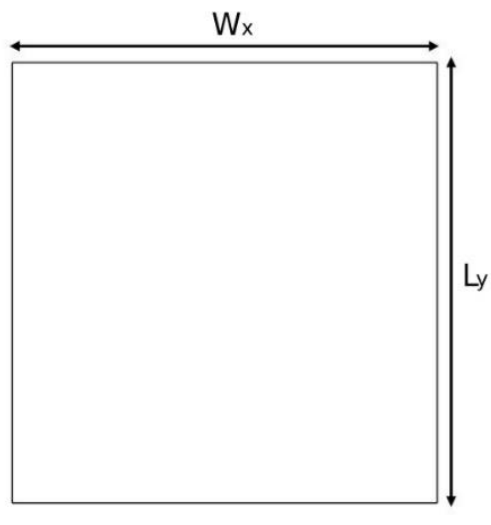

b

Fig. 1 - The geometry of the MCPM antenna: (a) front view and (b) back view. The ealized variables of the MCPM antenna are as follows: $W_{x}=15, L_{y}=15, H=1.575, S_{x}=14.2, S_{y}=9.8, S_{t}=0.4, S_{h}=1.4, R=3.9, C_{1}=5.7, C_{2}=3.47, C_{3}=1.96, G_{x}=3.3, G_{y}=5.5$, $F_{x}=3.93, F_{y}=1$ (all dimensions are in $\mathrm{mm}$ )

The dielectric constant $\left(\varepsilon_{r}\right)$ of the proposed substrate is 2.2 with a dissipation factor $\tan \delta$ equal to 0.0004 . The total dimensions of the suggested antenna are $15 \mathrm{~mm} \times 15 \mathrm{~mm} \times 1.575 \mathrm{~mm}$ of $W_{x} \times L_{y} \times H_{t}$. The MCPM antenna consists of a modified circular patch embedded with three small circles $\left(C_{1}, C_{2}, C_{3}\right)$ to improve the antenna impedance bandwidth. The antenna was fed by a $50 \Omega$ coplanar waveguide (CPW), which gives it the ability to be integrated and combined with the printed circuit board (PCB).

To determine the most proper antenna design, five different cases with exact exterior sizes were successfully simulated and analyzed. The provided examples are in a circular disk shape (case 1), a semicircular shape (case 2), a semicircular shape with a small circle (case 3), a semicircular shape with two small circles (case 4), a semicircular shape with three small circles (case 5). These antenna cases are duplicated in Fig. 2.

Simulation of the reflection coefficient $\left(S_{11}\right)$ of the proposed antennas in five cases is presented in Fig. 3. The dimensions of the CPW-fed antenna are used for the entire process and fixed at $W_{x}=W_{y}=15 \mathrm{~mm}$, $G_{x}=3.3 \mathrm{~mm}$ and $G_{y}=5.5 \mathrm{~mm}$. Meanwhile, $S_{x}$ and $S_{y}$ are set at $14.2 \mathrm{~mm}$ and $9.8 \mathrm{~mm}$, respectively, to achieve a $50 \Omega$ impedance connection. The design process starts from the basic circular disk structure (case 1) with a radius of $3.9 \mathrm{~mm}$, as shown in Fig. 2, which means that the circle diameter is equal to $D=2 \times R=7.8 \mathrm{~mm}$. However, the antenna in case 1 starts to radiate to achieve a bandwidth of $6.8 \mathrm{GHz}$ from 4.9 to $11.7 \mathrm{GHz}$, as shown in Fig. 3. Then, the circular patch was cut in half, as shown in Fig. 2 as case 2. The final stage (case 5) is to attach one more circle to become four radiating circles, which helps to improve the impedance circuit matching. Moreover, this decreases the electromagnetic coupling between the antenna and the CPW feed line, leading to matching circuit goals. The final design obtains a bandwidth ranging from 3 up to $11 \mathrm{GHz}$, which is enough to cover the UWB frequencies and more.

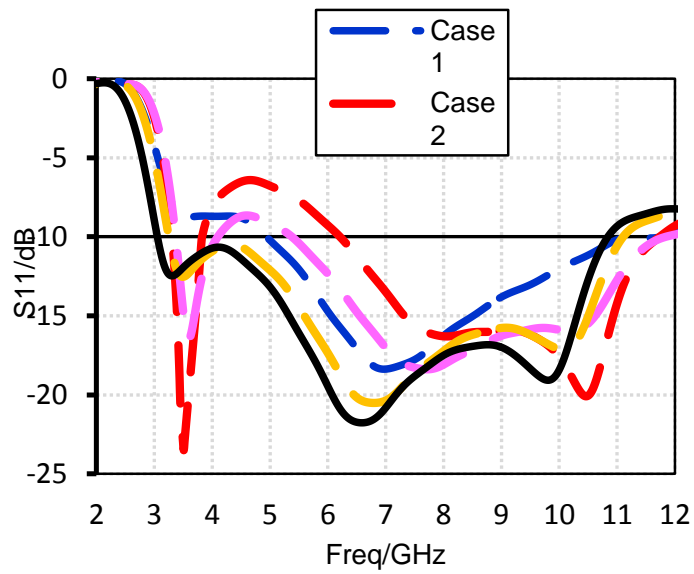

Fig. 3 - Simulated reflection coefficient $\left|S_{11}\right|$ of the suggested antennas from case 1 to case 5 


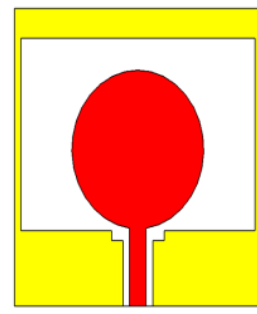

Case 1

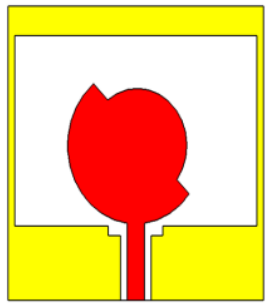

Case 3

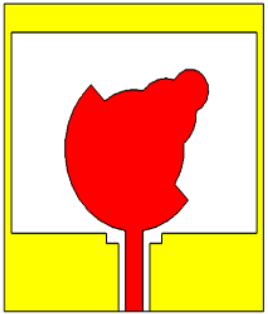

Case 5

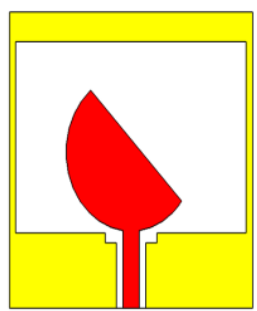

Case 2

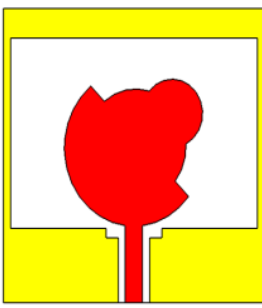

Case 4
Fig. 2 - Development stages of the stated MCPM antenna

\section{SIMULATION RESULTS AND ANALYSIS}

The proposed MCPM antenna has been successfully simulated using CST software. The simulation results are obtained for the antenna design presented in case 5, which is considered to be the best result compared to other antennas in different cases. The finalized antenna exhibited a bandwidth of $8 \mathrm{GHz}$ from 3 to $11 \mathrm{GHz}$ with $114 \%$ fractional bandwidth (FBW \%). The voltage standing wave ratio (VSWR) of the proposed MCPM antenna is duplicated in Fig. 4. It is clear that the antenna maintained a bandwidth for VSWR less than two (VSWR $<2$ ), which is from 3 up to $11 \mathrm{GHz}$.

Fig. 5 illustrates the simulated radiation patterns at various frequencies such as 3,6 and $11 \mathrm{GHz}$ in both $E$ and $H$ plane directions. There is a similar behavior

\section{VSWR}

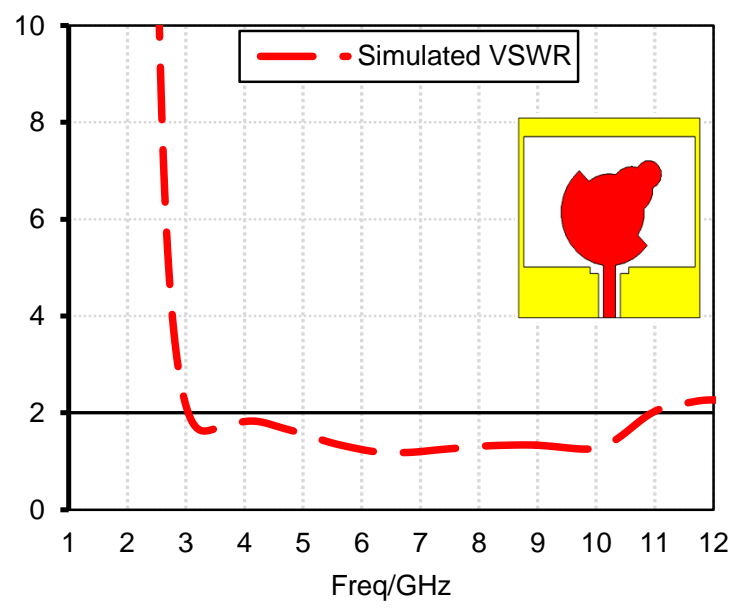

Fig. 4 - Simulated VSWR

among them. Besides, the designs show excellent frequency balance. The stated MCPM antenna has highquality omnidirectional radiation in the $H$-plane and almost eight forms of transmission in the $E$-plane.

Fig. 6 presents the simulated results of the proposed UWB MCPM antenna in terms of gain, directivity, and radiation efficiency. From Fig. 6, the proposed antenna exhibits a peak realized gain of $3.2 \mathrm{~dB}$ at $11 \mathrm{GHz}$. Meanwhile, in the lower frequency band of $3 \mathrm{GHz}$, the gain is about $0.3 \mathrm{~dB}$, which is acceptable due to the very small antenna size. From Fig. 6, the maximum directivity of $3.9 \mathrm{dBi}$ is obtained at $11 \mathrm{GHz}$ and of $2.4 \mathrm{dBi}$ - at $3 \mathrm{GHz}$. Thus, it is clear that the directivity is higher at higher frequencies, as opposed to a lower frequency range. Fig. 6 also shows that the radiation efficiencies of the proposed antenna are about $58 \%$ and $85 \%$ at $3 \mathrm{GHz}$ and $11 \mathrm{GHz}$, respectively. The antenna efficiency is higher than $70 \%$ in the entire UWB frequency range.

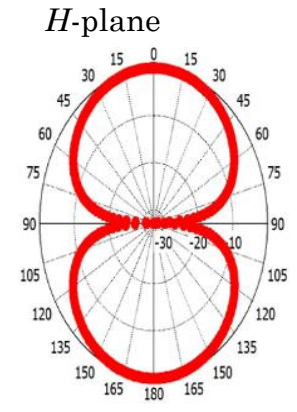

Simulated UWB MCPM antenn
$E$-plane

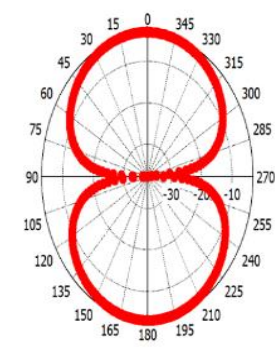

Simulated IWB MCPM antenna

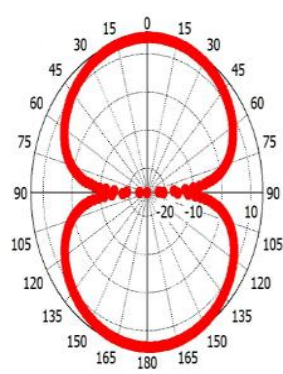

Simulated UWB MCPM antenna

$b$

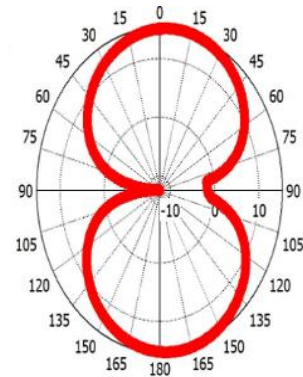

Simulated UWB MCPM antenn

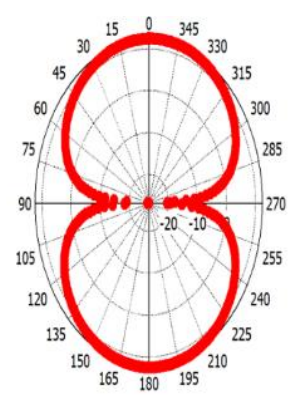

Simulated UWB MCPM antenna

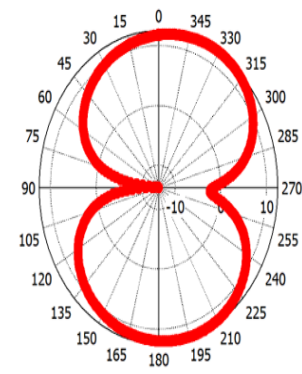

Simulated UWB MCPM antenna
Fig. 5 - Radiation properties in the $H$ and $E$ planes for frequencies: (a) $3 \mathrm{GHz}$, (b) $6 \mathrm{GHz}$, and (c) $9 \mathrm{GHz}$ 


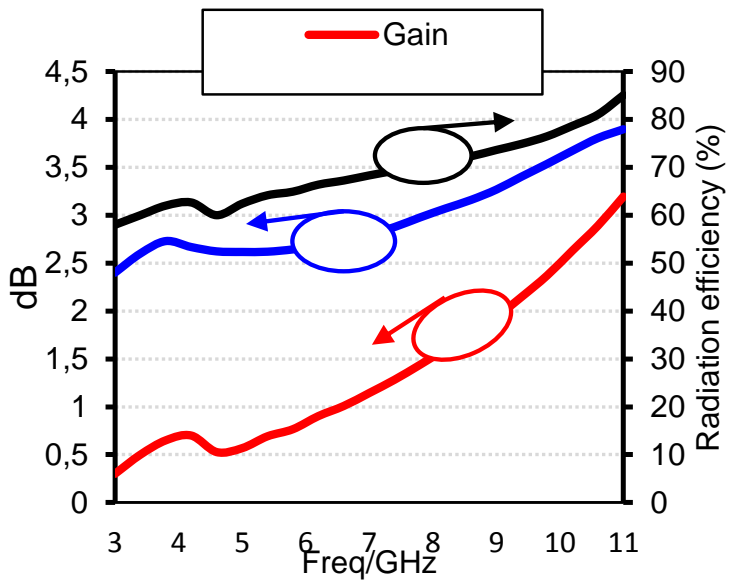

Fig. 6 - Simulated combo chart results of the proposed antenna in terms of gain, directivity, and radiation efficiency

\section{REFERENCES}

1. Federal Communications Commission, FCC02-48 (2002).

2. S. Kim, Y. Kim, X. Li, J. Kang, IEEE Commun. Lett. 17, 896 (2013).

3. L. Aguni, S. Chabaa, S. Ibnyaich, A. Zeroual, J. NanoElectron. Phys. 13, 02032 (2021).

4. A.J.A. Al-gburi, I.M. Ibrahim, Z. Zakaria, Int. J. Appl. Eng. Res. 12, 4782 (2017).

5. I.M. Ibrahim, A.J.A. Al-gburi, Z. Zakaria, H.A. Bakar, J. Telecommun. Electron. Comput. Eng. 10, 53 (2018).

6. A.J.A. Al-gburi, I.M. Ibrahim, Z. Zakaria, J. Comput. Theor. Nanosci. 17, 1469 (2020).

7. A.Z. Manouare, D. Seetharamdoo, S. Ibnyaich, A. El Idrissi, A. Ghammaz, J. Nano- Electron. Phys. 10, 01009 (2018).

8. J. Liang, C.C. Chiau, X. Chen, C.G. Parini, IEEE Trans. Antennas Propag. 53, 3500 (2005).

\section{CONCLUSIONS}

A printed UWB monopole antenna of small size and simple structure is presented in this paper. The antenna has a $114 \%$ fractional bandwidth from 3 to $11 \mathrm{GHz}$, covering the entire UWB frequency band and more. Comprehensive parametric studies are conducted based on the main antenna design parameters. The optimal antenna design is achieved utilizing CST studio. The total physical dimensions of the finalized antenna are $15 \mathrm{~mm} \times 15 \mathrm{~mm} \times 1.575 \mathrm{~mm}$. The miniaturization and wide bandwidth of the proposed antenna make it preferable for many wireless and communication applications.

\section{ACKNOWLEDGEMENTS}

We would like to thanks to Ministry of Higher Education and UTeM through FRGS Grant F00430 FRGS/1/2020/FKEKK-CETRI/F00430 that support this research.
9. S. Mukherjee, A. Roy, S. Bhunia, J. Nano- Electron. Phys, 13, 03026 (2021).

10. U. Keshwala, S. Rawat, K. Ray, J. Nano- Electron. Phys. 13, 02018 (2021)

11. A.J.A. Al-gburi, I.M. Ibrahim, M.Y. Zeain, Z. Zakaria, IEEE Access 8, 92697 (2020).

12. K.P. Ray, S.S. Thakur, Wirel. Pers. Commun. 109, 1689 (2019).

13. H.A. Mohamed, A.S. Elkorany, S.A. Saad, D.A. Saleeb, Prog. Electromagn. Res. C 76, 197 (2017).

14. S. Rawat, U. Keshwala, K. Ray, Int. J. Electr. Electron. Eng. Telecommun. 7, 66 (2018)

15. A.J.A. Al-gburi, I.M. Ibrahim, Z. Zakaria, M.Y. Zeain, H. Alwareth, A.M. Ibrahim, H.H. Keriee, Prz. Elektrotechniczny 2, 165 (2021).

\title{
Ультра-мініатюрна МСРМ антена для надширокосмугових застосувань
}

\author{
Ahmed Jamal Abdullah Al-Gburi, Imran Mohd Ibrahim, Zahriladha Zakaria \\ Faculty of Electronics and Computer Engineering, Universiti Teknikal Malaysia Melaka (UTeM), \\ Hang Tuah Jaya, 76100 Durian Tunggal, Melaka, Malaysia
}

\begin{abstract}
В роботі запропонована ультра-мініатюрна модифікована кругла друкована монопольна (МСРМ) антена для надширокосмугових (UWB) застосувань. Запропонована антена складається з чотирьох круглих дисків, з'еднаних зі структурою МСРМ антени, що призводить до збільшення пропускної здатності антени. Заявлена МCPM антена живиться від копланарного хвилевода (CPW) для узгодження імпедансу 50 Ом. Для моделювання конструкції використовувалася підкладка Rogers RT5880 $\left(\tan \delta=0,0004\right.$ і $\left.\mathcal{E}_{r}=2,2\right)$. Запропонована MCPM антена для UWB застосувань розроблена та змодельована для частот від 3 до 11 ГГц за допомогою технології комп'ютерного моделювання (CST). MCPM антена успішно спроектована та змодельована, а її параметричне дослідження виконано комплексно, щоб підтвердити новизну конструкції. Крім того, запропонована антена демонструе стабільну діаграму випромінювання з гарним підсиленням в робочій смузі. Зазначена антена також порівнюеться 3 відповідними літературними даними, щоб диференціювати їі продуктивність. Загальний розмір завершеної МСРМ антени становить $0,15 \lambda_{0} \times 0,15 \lambda_{0} \times 0,0016 \lambda_{0}$, що відповідае найнижчій робочій частоті 3 ГГц. Допрацьована МСРМ антена досягає пікового підсилення 3,2 дБ і спрямованості 3,9 дБі з високим ККД 85 \% на частоті 11 ГГц. Крім того, антена пропонуе достатньо широку пропускну здатність для використання в UWB додатках та радіозв'язку.
\end{abstract}

Ключові слова: МСPM антена, Ультра-мініатюрна, Підсилення, Надширокосмугова (UWB), Копланарний хвилевід (CPW). 